\section{The relationship between the choice of place of delivery and childbirth labor with the inci- dence of infant mortality in Sorawolio community health center working area of Baubau City, Indonesia}

\author{
Rininta Andriani, Risma \\ Public Health Faculty, Dayanu \\ Ikhsanuddin University, Indonesia
}

\begin{abstract}
Infant Mortality Rate (IMR) describes the success of the health sector and also directly relates to an average of population life expectancy in an area. This study aimed to investigate the relationship between place of delivery, childbirth labor with the incidence of infant mortality in the Community Health facility. This was an observational analytical research with a cross sectional study design. The population include 190 mothers who had given birth in 2017 in the Health facility, of which 60 people were selected using stratified random sampling technique. Data was collected through primary information requisition by using questionnaires and secondary data was collected from the Community Health Center and the Health Office of Baubau City. The data was analyzed using the chisquare test. The results indicated that there was a significant relationship between the place of delivery $(p$ value $=0.004, p<0.005)$ and childbirth labor $(\mathrm{p}$ value $=0.006$, $\mathrm{p}<0.005)$ with the incidence of infant mortality in the Community Health facility.
\end{abstract}

\section{Introduction}

Infant Mortality Rate (IMR) is an indicator of the health status of the society, ${ }^{1}$ which describes the success and development of the health sector as well as the average life expectancy of its population.

According to the global reports of the WHO (2015), 2.7 million infants die during the neonatal period, constituting approximately $45 \%, 58 \%$ and $75 \%$ of under-5, infant and first week of birth mortality, respectively, most of which occur in low and middle-income countries, that therefore accounts for its growing proportion. A continuity of this trend is further projected to increase the share percentage from $45 \%$ in 2015 to $52 \%$ in
2030. 2 The Indonesian Demographic and Health Survey (SKDI) in 2012, stated that infant mortality rate was about 32 per 1000 live births, which then decreased in 2015 to 27 per 1000 live births. In Southeast Sulawesi, this was recorded to be 8 per 1000 live deliveries in 2015 and in 2016 it further reduced to 7 per 1000 live births. Statistics from the city of Baubau, indicates the rate in 2015 as 2 per 1000 live births and 2 per 1,000 in $2016 .^{3}$

The main causes of these deaths in the world include, premature babies (29\%), sepsis and pneumonia (25\%) and (23\%) respectively, while babies who are born with asphyxia ranks third as the reason for infant mortality in the world (WHO, 2012). Furthermore, in Indonesia, the most common problem implicated in child mortality includes asphyxia, low birth weight and infection. Data on the child health program, held in 2015 in Southeast Province, indicate the main cause of neonatal deaths were, 125 cases of Low Birth Weight (31\%), 85 asphyxia (21\%), 47 issues of congenital anomalies (12\%), 5 jaundice $(1 \%)$ and 138 cases of others $(34 \%))^{3}$

Contemporarily, the affordability and the distance to health facilities greatly affect the choice of place and childbirth labor, especially for villagers, far from hospital, who eventually give birth at home. Childbirth assistance involves traditional deliveries, utilizing conventional methods, which tend to harm and endanger the safety of mothers and newborns. ${ }^{4}$

Factors associated with neonatal mortality in Tapin Tinjauan District, 62.5\% were as a result of non-health labor/traditional childbirth methods. ${ }^{5}$ Previous study showed stated that there was no relationship between the processes of birth, childbirth labor and place of birth with infant mortality. ${ }^{6}$ Meanwhile an association was found between these parameters, which was observed from the $\mathrm{p}$ value $<0.05$ and $\mathrm{OR}$ value of $0.61(95 \% \mathrm{CI}$ $0.40-0.91)$. Furthermore, there was no significant relationship between the components of ANC 5T plus, childbirth labor and types of labor with child death. ${ }^{7}$

Based on data of the Health Profile of Southeast Sulawesi Province, achievement of successful delivery assistance by health workers in 2016 amounted to $80.85 \%$, which was less than $88.21 \%$, recorded in 2015. The highest childbirth labor were carried out by midwives $(68.6 \%)$, then doctors $(18.5 \%)$, traditional birth attendants $(11.8 \%)$, without helpers $(0.8 \%)$ and nurses $(0.3 \%)$. Furthermore, the increasing coverage of health care for delivery has not been matched by the elevating number of
Correspondence: Rininta Andriani, Public Health Faculty, Dayanu Ikhsanuddin University, Jalan Sultan Dayanu Ikhsanuddin nomor 124, Betoambari Baubau Sulawesi Tenggara 93752, Indonesia.

Tel.: +62.402.2821327 - Fax: +62.402.2826682. E-mail: rinintaandriani82@gmail.com.

Key words: infant mortality, place of delivery, childbirth labor.

Acknowledgment: the authors would like to thank Public Health Faculty, Dayanu Ikhsanuddin University.

Contributions: the authors contributed equally.

Conflict of interest: the authors declare no potential conflict of interest.

Funding: none.

Clinical trials: the study is not involved any clinical trials.

Conference presentation: part of this paper was presented at the $3^{\text {rd }}$ International Symposium of Public Health, 2018 October 31 - November 1, Universitas Airlangga, Surabaya, Indonesia

Dedication: the article is dedicated to Public Health Faculty, Dayanu Ikhsanuddin University.

Received for publication: 28 July 2019.

Revision received: 9 September 2019.

Accepted for publication: 15 October 2019.

This work is licensed under a Creative Commons Attribution NonCommercial 4.0 License (CC BY-NC 4.0).

CC Copyright: the Author(s), 2019

Licensee PAGEPress, Italy

Journal of Public Health in Africa 2019; 10(s1):1196 doi:10.4081/jphia.2019.1196

childbirth in health care facilities, which could be seen from the high number of home deliveries $(65.67 \%)$ and about $34.37 \%$ in health facilities. This ratio was estimated to be due to the strong culture that childbirth is to be carried out naturally by traditional childbirth attendants. ${ }^{8}$

At Sorawolio Community Health Center, data obtained within 2016-2017 indicated a percentage decline in the amount of women who chose this facility and its practitioners for delivery as a reduction by $4.54 \%$ was observed in 2016 and $2.11 \%$ in 2017 . Conversely assistance by non-health workers (traditional childbirth labor) increased as this rose by $1.704 \%$ in 2016 and $2.11 \%$ in 2017.9 
Statistics show that $21 \%$ of delivery by competent health workers were carried out in health facilities while those carried out in non-health facilities (home) reached $38.23 \%$ (January - December 2017 period). However, this comparative increase is not without problems as in 2017 , in the working area of Sorawolio Community Health Center of Baubau city there were 3 (three) cases of infant mortality recorded, in which the process was assisted by a traditional childbirth labor, in a non-health facility (home). This community health facility was further regarded as one with the highest IMR in comparison with home delivery, as seen in Waborobo, Lowu-Lowu and Wajo Community Health Center working areas, where the cases of child death were recorded. ${ }^{9}$

Prior studies have shown that the choice of a place for birth between non-health facilities (at home) and delivery laborers (traditional childbirth labor) correlated with infant deaths. This was because of the strong belief in traditional system and that there were still many people who did not understand the importance of childbirth by a health worker.

The objective of this research furthermore was to investigate the relationship between the decision of place for delivery and childbirth attendant involved with the incidence of infant mortality in Sorawolio Community Health Center working area of Baubau City.

\section{Materials and Methods}

This research was an observational study, using an analytical approach with a cross sectional study design and conducted in Sorawolio Community Health Center working area on July 2018. 60 mothers who had given birth was involved by using stratified random sampling technique. Primary data were collected through the use of questionnaires and secondary data from articles, books, journals, and profile of the Health facility, which were further analyzed by univariate analysis and bivariate analysis, using the chi-square test $\left(\chi^{2}\right)$.

\section{Results}

\section{Characteristic of demographic, socio-cultural and economy}

Sorawolio Community had a population of 8,375 people, with 4,097 males and 4,278 females and a total of 1,871 families. Furthermore, this population was predominated by the Cia-cia tribe, with Islam being the main religion (approximately 99\%) and only $1 \%$ of them practiced others. The behavior of the society was strongly influenced by local customs, such as unity, manifested in solid mutual cooperation which could be seen in events, such as salvation, weddings and others that reflect the local culture or customs. The livelihoods of the population in general were based on garden farming and public transportation (petepete/public cars) and taxi bikes were the dominant means for mobility.

\section{Distribution of number of health facilities}

Table 1 indicates the number and distribution of health facilities in 2017 .

\section{Univariate analysis}

The research consisted of four independent variables, which include delivery in health facility (community health center), in non-health facility (home), by assistance of midwife and by the assistance of traditional childbirth labor. Conversely, the dependent variable was infant mortality.

\section{Place of delivery}

Table 2 summarizes the distribution of respondents, based on delivery place, delivery assistance and infant mortality rate.

\section{Bivariate analysis \\ The relationship between delivery place and infant mortality incidence}

Table 3 showed that 11 respondents (73.3\%) indicated to have not chosen the health facility as the place for delivery, while 4 subjects $(26.7 \%)$ did. Conversely, 14 people $(31.3 \%)$ indicated to have not had their births carried out in non-health facilities, while 31 respondents $(68.9 \%)$ indicated to have carried out their deliveries there.

Based on statistical analysis, using chisquare test with a significant level of $95 \%$, the $p$ value $=0.004$ was obtained and there was no relationship between the place of delivery and the incidence of infant mortality in the working area of Sorawolio Community Health Center in Baubau City.

The relationship between delivery assistance labor and infant mortality incidence

Table 4 showed that deliveries carried out by midwife/doctor did not take place with 0 respondents $(0 \%)$, while $9(100 \%)$ successfully materialized. However, people who stated traditional childbirth labor with respondents that not occur were $25(49 \%)$ while those that did were $26(51 \%)$. Based on the statistical test, using the chi-square test with a significant level of $95 \%$, the $\mathrm{p}$ value obtained was 0.006 , indicating a relationship between delivery assistance labor and the incidence of infant mortality in Sorawolio Community Health Center working area in Baubau City.

Table. 1. Number of Health Facilities in Sorawolio Community Health Center of Baubau City in 2017.

\begin{tabular}{llcc} 
No & Sub-district & Village Health Post (Poskesdes) & Posyandu \\
1. & Kaisabu Baru & 1 & 6 \\
2. & Karya Baru & 1 & 2 \\
\hline 3. & Bugi & 1 & 2 \\
4. & Gonda Baru & 1 & 2 \\
\hline Total & & 4 & 12 \\
\hline
\end{tabular}

Table 2. Distribution of Respondent, based on Place of Delivery, Delivery Assistance Labor, Infant Mortality.

\begin{tabular}{lcc} 
Place of Delivery & Frequency (n) & Percentage (\%) \\
Health Facilities & 15 & 25 \\
Non-Health Facilities & 45 & 75 \\
\hline Total & 60 & 100 \\
Delivery Assistance Labor & & \\
Midwife/Doctor & 9 & 15 \\
Traditional Childbirth Labor & 51 & 85 \\
Total & 60 & 100 \\
Infant Mortality & & \\
Not Happened & 25 & 41.7 \\
Happened & 35 & 58.3 \\
Total & 60 & 100
\end{tabular}




\section{Discussion}

Relationship between places of delivery with the incidence of infant mortality at working area of

\section{Sorawolio Community Health}

\section{Center of Baubau city}

The most ideal place for childbirth is the health facility, with equipment and personnel, readily available at any time of complications as seen in their ability to give obstetrics and Basic Emergency Neonate (PONED) and if choosing childbirth at home appropriate preparations must be made, the helper, place, tools, environment and material carried by helper, must be adequately prepared as well as the family.

The statistical test result, using chi square at $95 \%$ level of significance, obtained $p$ value $0.000<0.05$, therefore there was no correlation between places of delivery with the incidence of infant mortality.

The 15 mothers who chose the health facility encompassed 11 respondents who decided to carry out their delivery there but it did not happen because they already understood the safety of this place of delivery for the child and herself. Furthermore, 4 subjects stated that their presence in the health facility was due to an already complicated situation, which include, amniotic fluid dry up hence the baby was threatened with asphyxia. Those who stated chose nonhealth facility were 45 respondents, consisting of 14 who entered fast labor and also those who had their childbirth at mid night, however, the mother and child were in good condition. furthermore, the 31 respondents took this decision because they wanted to be in the midst of the family during the process because they believe supports from family is very important which gives her the strength to accept whatever risk that could occur.

Based on the result obtained on the place of delivery, there were claims that mothers give birth without using community health care, though childbirth at community health center was free of charge through Jampersal program because it was seen as a disgrace to the family. Hence they sought medical attention only when the process could not be handled at home. Furthermore, this also happens when they do not get the adequate support from husband and family.

This research is similar with previous study conducted by Tyagita Widya Sari (2010) where there was correlation between place of delivery with the incident of infant mortality. ${ }^{7}$ Childbirth which is done at home with the help of traditional childbirth attendants caused the high maternal and infant mortality rates and those conducted at home with the help of skilled health workers like midwife did not reduce the numbers. Therefore, the delivery process must be conducted at a health facility with the help of medical personnel.

\section{The relationship between childbirth labors with the incidence of infant mortality at working area of Sorawolio Community Health Center of Baubau city}

Childbirth attendants (labor) are people who are needed to assist a pregnant woman during the process of delivery. They are divisions of health workers (midwife/doctor), who are already competent in offering assistance to the mother. Conversely, tradi- tional childbirth attendants are figures that are highly trusted in the community as they give special treatment to pregnant women until postpartum patiently and the community feels comfortable and relaxed, if their deliveries were carried out with their help. Furthermore, midwifery owned by the traditional practitioners are very limited because they are usually obtained by hereditary (not developed)

Based on the result of statistical test, using chi square at $95 \%$ level of significance, the $\mathrm{p}$ value obtained $=0.00<0.05$, which indicates that there is no correlation between childbirth labor and the incidence of infant mortality at working area of Sorawolio Community Health Center of Baubau city.

Mothers who stated to have chosen midwife/doctor as the childbirth labor were 9 , consisting of 0 respondent who choose not happen for midwife/doctor because they were knowledgeable that midwife helps the process and provide the best services, such as weigh the baby, caring for the infant, give postpartum service to the mother and also identify any signs of risks that could occur to the mother and her baby. Conversely, 9 respondents stated that they decision to involve midwife/doctor happens because at the process of childbirth, the mother is in an unstable condition because they rarely check their pregnancy, leading to the baby being born in fetal distress condition, such as difficulty in breathing. Those who choose giving birth with traditional attendants were 51 respondents which consisted of 25 who choose these practitioners and it happened, because the mother is holding tightly to the family believes and further considers that traditional childbirth attendants are more experienced in giving care to

Table 3. The Relationship between Delivery Place and Infant Mortality Incidence in Sorawolio Community Health Center Working Area of Baubau City.

\begin{tabular}{|c|c|c|c|c|c|c|c|}
\hline \multirow[t]{3}{*}{ Delivery Place } & \multicolumn{4}{|c|}{ Infant Mortality Incidence } & \multirow{2}{*}{\multicolumn{2}{|c|}{ Total }} & \multirow[t]{3}{*}{ P value } \\
\hline & \multicolumn{2}{|c|}{ Not happened } & \multicolumn{2}{|c|}{ Happened } & & & \\
\hline & $\mathbf{N}$ & $\%$ & $\mathbf{N}$ & $\%$ & $\mathbf{N}$ & $\%$ & \\
\hline Health Facilities & 11 & $73.3 \%$ & 4 & $26.7 \%$ & 15 & $100 \%$ & 0.004 \\
\hline Non Health Facilities & 14 & $31.3 \%$ & 31 & $68.9 \%$ & 45 & $100 \%$ & \\
\hline Total & 25 & $41.7 \%$ & 35 & $58.3 \%$ & 60 & $100 \%$ & \\
\hline
\end{tabular}

Table 4. The Relationship between Delivery Assistance Labor and Infant Mortality Incidence in Sorawolio Community Health Center Working Area of Baubau City.

\begin{tabular}{|c|c|c|c|c|c|c|c|}
\hline \multirow[t]{3}{*}{ Delivery Assistance Labor } & \multicolumn{4}{|c|}{ Infant Mortality Incidence } & \multirow{2}{*}{\multicolumn{2}{|c|}{ Total }} & \multirow[t]{3}{*}{ P value } \\
\hline & \multicolumn{2}{|c|}{ Not happened } & \multicolumn{2}{|c|}{ Happened } & & & \\
\hline & $\mathbf{N}$ & $\%$ & $\mathbf{N}$ & $\%$ & $\mathbf{N}$ & $\%$ & \\
\hline Midwife/Doctor & 0 & $0 \%$ & 9 & $100 \%$ & 9 & $100 \%$ & 0.006 \\
\hline Traditional Childbirth Labor & 25 & $49.0 \%$ & 26 & $51.0 \%$ & 51 & $100 \%$ & \\
\hline Total & 25 & $41.7 \%$ & 35 & $58.3 \%$ & 60 & $100 \%$ & \\
\hline
\end{tabular}


the mother and her baby, therefore, they utilize this means every time. Furthermore, 26 subjects who choose these attendants and it happened was because the mother believes that their skills in dealing with process, however these practitioners know little about the danger signs that occur to the mother and her baby.

This research outcome is similar with that conducted by Noorhalimah (2015) which stated that there is correlation between infant mortality and the childbirth labor used. ${ }^{5}$ Deliveries that involve the help of traditional childbirth labor pose greater risk of neonatal death in comparison with births with the assistance of medical personnel. Therefore, this illustrates that traditional practitioners are risk factors of neonatal death and pain as it can be understood that they do not know the danger signs during the process, consequently improper handling of childbirth further leading to asphyxia and fetal death in uterus.

\section{Conclusions}

It can be concluded that there is a correlation between the place of delivery and the incidence of infant mortality at working area of community health center of Baubau city. Additionally, there is also a positive relationship between childbirth labors and the incidence of child death.

\section{References}

1. Mukherjee A, Bhattacherjee $\mathrm{S}$, Dasgupta S. Determinants of Infant Mortality in Rural India: An Ecological Study. Indian Journal of Public Health 2019;63(1):27-32.

2. Berhe AK, Tinsae F, Gebreegziabher G. Knowledge and practice of immediate newborn care among health care providers in eastern zone public health facilities, Tigray, Ethiopia, 2016. BMC Pediatr. 2017;17(1):157.

3. Badan Pusat Statistik. Survey Demografi dan Kesehatan Indonesia 2012. Available from: http://kesga.kemkes.go.id/images/pedoman/SDKI\%202012-Indonesia.pdf. Accessed on: 21 September 2018.

4. Kementerian Kesehatan Republik Indonesia. Pedoman Pelaksanaan Kemitraan Bidan Dan Dukun. Jakarta: Kementerian Kesehatan Republik Indonesia; 2008.

5. Noorhalimah N. Faktor-Faktor Yang Berhubungan Dengan Kematian
Neonatal Di Kabupaten Tapin Tinjauan Terhadap Pemeriksaan Kehamilan, Penolong Persalinan dan Karakteristik Ibu. Jurnal Publikasi Kesehatan Masyarakat Indonesia 2015;2(1):64-71.

6. Widayanti DA, Wijayanti AC. FaktorFaktor yang Berhubungan dengan Kematian Bayi di Kabupaten Boyolali. Available from: http://repository.urecol.org/index.php/proceeding/article/vi ew/254/250. Accessed on: 10 January 2018.

7. Sari TW, Syarif S. Hubungan Prematuris Dengan Kematian Neonatal di Indonesia. Jurnal Epidemiologi Kesehatan Indonesia 2016;1(1):9-14.

8. Departemen Kesehatan Republik Indonesia. Profil Kesehatan Provinsi Sulawesi Tenggara 2017. Available from: http://www.depkes. go.id /resources/download/profil/PROFIL_K ES_PROVINSI_2017/28_Sultra_2017. pdf. Accessed on: 20 January 2018.

9. Departemen Kesehatan Republik Indonesia. Profil Kesehatan Kota BauBau 2017. Available from: http://www.depkes.go.id/resources/dow nload/profil/PROFIL_KAB_KOTA_20 17/7472_Sultra_Kota_Baubau_2017.pd f. Accessed on: 20 January 2018. 